\title{
Lipid studies in the blood and brain in multiple sclerosis and motor neurone disease
}

\author{
J. N. CUMINGS, R. C. SHORTMAN, AND T. SKRBIC \\ From the Department of Chemical Pathology, Institute of Neurology, \\ The National Hospital, Queen Square, London
}

SYNOPSIS The lipid patterns of plasma, red blood cells, and leucocytes from normal controls and from patients with multiple sclerosis and motor neurone disease have been studied by thin-layer chromatography. The fatty acid composition of cholesterol esters and lecithin in plasma from normal subjects and from patients with multiple sclerosis are reported. The fatty acid composition of lecithin of cerebral white matter from normal control subjects, from multiple sclerosis, and from motor neurone disease as well as of cholesterol esters in multiple sclerosis are recorded and compared. No significant abnormalities were found in the blood lipid profile in multiple sclerosis, but in motor neurone disease red cell sphingomyelin was slightly reduced and white cell lecithin slightly increased. The fatty acids of plasma cholesterol esters showed a slight decrease in palmitic and stearic acid in multiple sclerosis. The fatty acids in lecithin in multiple sclerosis, both in the apparently normal white matter and in the plaques, showed a slightly increased degree of saturation, while the loss of unsaturated acids was in oleic acids.

The lipid composition of brain, blood plasma, and cerebrospinal fluid in multiple sclerosis has attracted the attention of many workers in recent years. A rise in the cephalin level in the cerebrospinal fluid has been recorded (McArdle and Zilkha, 1962; Zilkha and McArdle, 1963) in the more acute stages of the disease, although other workers (Phillips and Robinson, 1963) did not obtain such a marked degree of abnormality. The lipid composition of the apparently normal white matter was shown to be abnormal in multiple sclerosis (Cumings, 1953), while Baker, Thompson, and Zilkha (1963) showed abnormalities in fatty acid composition in similar areas of the brain. They rezorded that there was a greater amount of saturated as compared with unsaturated fatty acid in brain lecithin than in the white matter of normal subjects. The relationship of this change to the aetiology of multiple sclerosis is as yet unknown, but it could represent the initial change in an altered myelin structure.

This paper records our findings in a study of the lipids in plasma, red blood cells, and white blood cells in normal subjects, in patients with multiple sclerosis and with motor neurone disease. The fatty acid composition of lecithin and of esterified

Received for publication 13 January 1965. cholesterol in cerebral white matter and in plasma has also been made in the same diseases.

\section{MATERIAL AND METHODS}

Blood was obtained from 14 patients with multiple sclerosis, from five with motor neurone disease, and from 11 control subjects who were not suffering from organic neurological disease. Plasma was obtained after centrifugation of citrated blood $(1 \mathrm{ml}$. of $3.8 \%$ sodium citrate to $9 \mathrm{ml}$. blood), and the red cells were obtained free from plasma. For the white blood cells the method of Lalezari (1961) using polybrene was employed.

Cerebral white matter from the frontal or parietal lobes was obtained from five normal controls, from four cases of multiple sclerosis, and from two of motor neurone disease at necropsy. Both apparently normal white matter as well as plaque material was obtained from the brains of the cases of multiple sclerosis.

The lipids from both blood and brain were extracted by the method of Folch, Lees, and Sloane Stanley (1957) and estimations of the total lipid phosphorus were performed using the Bartlett procedure as given by McArdle and Zilkha (1962), except that 1-amino-2 napthol-4 sulphonic acid (Eastman Kodak Company) was used in the final stages. The amount of lipid extract used was such as would contain between $0 \cdot 1 \mu \mathrm{g}$. and $1 \cdot 0 \mu \mathrm{g}$. phosphorus in each determination.

The lipid extracts from plasma, red blood cells, and 
white cells were examined by thin-layer chromatography (Müldner, Wherrett, and Cumings, 1962), the phosphoruscontaining compounds visualized by the use of $50 \%$ sulphuric acid, and the various fractions cut out and the phosphorus in each fraction estimated. Control runs of the same lipid extracts on the same plates were stained by the molybdate-perchloric acid reagent (Wagner, Hörhammer, and Wolff, 1961) to demonstrate the exact site and presence of a phosphorus-containing compound.

Lecithin and cholesterol esters in plasma and brain were prepared for examination for their fatty acid composition by the following techniques. The lecithin fraction, visualized as previously, was removed from each plate after preparative thin-layer chromatography, performed as for the phosphorus estimations but with a few modifications. The lipid extract was applied to the plate under a stream of nitrogen and the chromatography tank was filled with nitrogen before use. Cholesterol esters were prepared by the method of Brown and Johnston (1962) but with the use of $n$-heptane for $n$-hexane and without incorporating $2^{\prime}, 7^{\prime}$ dichlorofluorescin in the gel. The samples were spotted on the plates and run in a manner similar to those for lecithin. The cholesterol esters were located by spraying with $2^{\prime}, 7^{\prime}$ dichlorofluorescin, and by examining and removing them under ultraviolet light.

The methyl esters were prepared by the method of Stoffel, Chu, and Ahrens (1959), the transesterification step being performed in the presence of silicic acid but with microsublimation omitted. The analysis of the methyl esters was done by gas liquid chromatography using a Pye Panchromatogram at $180^{\circ}$, on a column of $20 \%$ polyethylene glycoladipate on celite and with a macro Argon ionization detector.

\section{RESULTS}

BLOOD Thin-layer chromatography of the lipids of plasma, red cells, and white cells showed four major components in all specimens similar to the findings of Robinson and Phillips (1963). These last workers claimed that they corresponded to lysolecithin, sphingomyelin, lecithin, and ethanolamine phosphatide. McArdle and Zilkha (1962), using silicic-acidimpregnated paper chromatography, included ino- sitol phosphatide with lysolecithin and serine phosphatide with the ethanolamine phosphatide. As shown by Müldner et al. (1962) thin-layer chromatographic separation as used here resulted in serine phosphatide being close to choline lysophosphatide, and with ethanolamine lysophosphatide near to choline phosphatide. However, for convenience the names given by Robinson and Phillips (1963) will be used although it is realized that two of the named compounds may not be present in an absolutely pure state.

The mean results obtained from the blood samples in all three diseases are recorded in Table I. The normal plasma total phospholipid figures differ little from those of either McArdle and Zilkha (1962) or Robinson and Phillips (1963) while the red cell totals hardly differ from the figures of Reed, Swisher, Marinetti, and Eden (1960). There are some small differences in the individual fractions, mainly in the plasma sphingomyelin and lecithin as compared with results of other workers in that their lecithin totals were slightly higher than those recorded here.

All the figures were submitted to statistical analysis and no significance was found for the total phospholipid or for any of the fractions in multiple sclerosis as compared with the normals. The results for sphingomyelin in the red cells in motor neurone disease, using Student's t test, gave a value of $P<0.05$ while in the white cell lecithin a figure of $\mathrm{P}<\mathbf{0 . 0 2}$ was calculated. None of the values for any of the other fractions in motor neurone disease was significant.

Table II shows the fatty acid analyses of plasma cholesterol esters in normal controls and in multiple sclerosis. The only differences between the patterns of fatty acids in multiple sclerosis as compared with the normal are in palmitic acid $(16: 0)$ and stearic acid $(18: 0)$, these saturated acids being decreased in multiple sclerosis giving figures of $\mathbf{P}<0.05$ and 0.02 respectively. There were no significant differences in any of the unsaturated acids, including

TABLE I

PHOSPHOLIPIDS IN PLASMA, RED BLOOD CORPUSCLES (R.B.C.), AND WHITE BLOOD CORPUSCLES (W.B.C.)

\begin{tabular}{|c|c|c|c|c|c|}
\hline & $\begin{array}{l}\text { Total } \\
\text { Phospholipid } \\
\text { Mean } \pm \text { S.D. }\end{array}$ & $\begin{array}{l}\text { Lysolecithin } \\
(\%) \\
\text { Mean } \pm \text { S.D. }\end{array}$ & $\begin{array}{l}\text { Sphingomyelin } \\
(\%) \\
\text { Mean } \pm \text { S.D. }\end{array}$ & $\begin{array}{l}\text { Lecithin }(\%) \\
\text { Mean } \pm \text { S.D. }\end{array}$ & $\begin{array}{l}\text { Ethanolamine } \\
\text { Phosphatide }(\%) \\
\text { Mean } \pm S . D .\end{array}$ \\
\hline $\begin{array}{l}\text { Plasma, control } \\
\text { Plasma, motor neurone disease } \\
\text { Plasma, multiple sclerosis }\end{array}$ & $\begin{array}{l}9 \cdot 52 \pm 1.97 \\
8.92 \pm 2 \cdot 7 \\
8.84 \pm 1 \cdot 31\end{array}$ & $\begin{array}{l}14.05 \pm 9.07 \\
17.44 \pm 6.0 \\
17.56 \pm 3.04\end{array}$ & $\begin{array}{l}23 \cdot 63 \pm 3 \cdot 09 \\
20 \cdot 12 \pm 4 \cdot 1 \\
25 \cdot 66 \pm 7 \cdot 58\end{array}$ & $\begin{array}{l}54.3 \pm 12.4 \\
54.74 \pm 4.97 \\
48.59 \pm 10.2\end{array}$ & $\begin{array}{l}8 \cdot 02 \pm 6 \cdot 71 \\
7 \cdot 7 \pm 5 \cdot 1 \\
7 \cdot 64 \pm 3 \cdot 94\end{array}$ \\
\hline $\begin{array}{l}\text { R.B.C., control } \\
\text { R.B.C., motor neurone disease } \\
\text { R.B.C., multiple sclerosis }\end{array}$ & $\begin{array}{l}13 \cdot 37 \pm 1 \cdot 8 \\
12 \cdot 7 \pm 2 \cdot 42 \\
13 \cdot 67 \pm 2 \cdot 05\end{array}$ & $\begin{array}{l}7 \cdot 27 \pm 4 \cdot 34 \\
9 \cdot 66 \pm 4 \cdot 92 \\
6 \cdot 57 \pm 4 \cdot 4\end{array}$ & $\begin{array}{l}32 \cdot 97 \pm 2 \cdot 05 \\
28 \cdot 38 \pm 3 \cdot 33 \\
31 \cdot 85 \pm 4 \cdot 79\end{array}$ & $\begin{array}{l}36 \cdot 1 \pm 16.9 \\
29 \cdot 86 \pm 4 \cdot 4 \\
31 \cdot 24 \pm 3 \cdot 35\end{array}$ & $\begin{array}{l}23 \cdot 33 \pm 10 \cdot 5 \\
30 \cdot 28 \pm 5 \cdot 28 \\
29 \cdot 5 \pm 5 \cdot 5\end{array}$ \\
\hline $\begin{array}{l}\text { W.B.C., control } \\
\text { W.B.C., motor neurone disease } \\
\text { W.B.C., multiple sclerosis }\end{array}$ & $\begin{array}{l}471 \cdot 0 \pm 187 \cdot 9 \\
521 \cdot 2 \pm 334 \cdot 9 \\
511 \cdot 0 \pm 255 \cdot 8\end{array}$ & $\begin{array}{c}11.13 \pm 6.3 \\
9.08 \pm 6.5 \\
10.68 \pm 4.79\end{array}$ & $\begin{array}{l}24 \cdot 31 \pm 3 \cdot 54 \\
20 \cdot 5 \pm 5 \cdot 01 \\
21 \cdot 46 \pm 6.43\end{array}$ & $\begin{array}{l}38 \cdot 23 \pm 2 \cdot 49 \\
42 \cdot 28 \pm 1 \cdot 9 \\
39 \cdot 26 \pm 4 \cdot 89\end{array}$ & $\begin{array}{l}26 \cdot 27 \pm 5 \cdot 88 \\
24 \cdot 44 \pm 6 \cdot 23 \\
28 \cdot 29 \pm 5 \cdot 08\end{array}$ \\
\hline
\end{tabular}

${ }^{1}$ Results for plasma in mg. $/ 100 \mathrm{ml}$., for R.B.C. in mg./100 ml. packed red cells, for W.B.C. in mg./100 ml. blood. 
TABLE II

FATTY ACID ANALYSIS OF PLASMA CHOLESTEROL ESTERS ${ }^{1}$

\begin{tabular}{|c|c|c|}
\hline Fatty Acids & $\begin{array}{l}\text { Normal } \\
\text { Mean } \pm \text { S.D. }\end{array}$ & $\begin{array}{l}\text { Multiple Scler } \\
\text { Mean } \pm \text { S.D. }\end{array}$ \\
\hline \multicolumn{3}{|l|}{ Saturated } \\
\hline $16: 0$ & $17 \cdot 18 \pm 1.94$ & $14.93 \pm 2.50$ \\
\hline $18: 0$ & $2.34 \pm 0.58$ & $1.67 \pm 0.63$ \\
\hline Total $^{2}$ & $23.05 \pm 2.63$ & $19.63 \pm 3.44$ \\
\hline \multicolumn{3}{|l|}{ Unsaturated } \\
\hline $16: 1$ & $7 \cdot 11 \pm 2 \cdot 46$ & $7.41 \pm 1.82$ \\
\hline $18: 1$ & $24.9 \pm 3 \cdot 18$ & $24 \cdot 14 \pm 2.51$ \\
\hline $18: 2$ & $36.9 \pm 4.83$ & $38.75 \pm 5.76$ \\
\hline $20: 4$ & $4.81 \pm 0.89$ & $5.21 \pm 0.38$ \\
\hline Total & $77.32 \pm 2.05$ & $79 \cdot 13 \pm 2.08$ \\
\hline
\end{tabular}

${ }^{1}$ Values are expressed as percentage of total fatty acid methyl esters. ${ }^{2}$ Traces of other acids were present in total.

linoleic acid. A review of the case material showed that the clinically more acute and the more advanced cases of multiple sclerosis did not show any significant biochemical differences as compared with the remainder of the patients in this group.

Table III shows the fatty acid analysis of plasma lecithin and no statistically significant abnormalities were found.

TABLE III

FATTY ACIDS IN LECITHINS IN PLASMA ${ }^{1}$

\begin{tabular}{|c|c|c|}
\hline Fatty Acids & $\begin{array}{l}\text { Normal } \\
\text { Mean } \pm S . D .\end{array}$ & $\begin{array}{l}\text { Multiple Scler } \\
\text { Mean } \pm \text { S.D. }\end{array}$ \\
\hline $\begin{array}{l}\text { Saturated } \\
14: 0 \\
16: 0 \\
18: 0 \\
\text { Total }^{2} \\
\text { Unsaturated } \\
16: 1 \\
18: 1 \\
18: 2 \\
20: 3 \\
20: 4 \\
\text { Total }\end{array}$ & $\begin{array}{r}1.65 \pm 0.68 \\
32.95 \pm 2.45 \\
12.70 \pm 1.13 \\
48.59 \pm 2.10 \\
\\
1.82 \pm 1.72 \\
16.99 \pm 2.44 \\
19.40 \pm 3.85 \\
2.40 \pm 0.62 \\
8.34 \pm 1.37 \\
50.63 \pm 2.87\end{array}$ & $\begin{array}{r}1.57 \pm 0.64 \\
33.88 \pm \mathbf{4} .04 \\
13.86 \pm 3.21 \\
50.19 \pm 3.92 \\
\\
2.32 \pm 1.23 \\
16.61 \pm 2.40 \\
18.67 \pm 2.46 \\
2.28 \pm \mathbf{0 . 7 3} \\
8.06 \pm \mathbf{1} \\
49.59 \pm \mathbf{3 . 8 7}\end{array}$ \\
\hline
\end{tabular}

${ }^{1}$ Values are expressed as percentage of total fatty acid methyl esters ${ }^{2}$ Traces of other acids were present in total.
BRAIN The fatty acid composition of lecithin in the white matter of normal controls and in motor neurone disease, and of apparently normal white matter in multiple sclerosis, and in the plaques in multiple sclerosis is given in Table IV. There is a slight increase in saturated and a slight decrease in unsaturated acids in the apparently normal white matter in multiple sclerosis (in both $P<0 \cdot 1$ ), with the greater change $(P<0.01)$ in oleic acid $(18: 1)$, while in the plaques the same changes are evident with the figure for oleic acid $(18: 1)$ being $P<0.05$, when compared with normal white matter.

The figures for the fatty acids in cholesterol esters in the plaques in multiple sclerosis are included in Table IV. Comparison with cholesterol esters from a normal brain is not possible as these are not found or are only present in trace amounts, but there is a very considerable difference from the plasma cholesterol ester fatty acid composition.

\section{DISCUSSION}

It was hoped that some abnormality would have been found in the lipid composition of the blood in multiple sclerosis and in motor neurone disease for both these diseases produce severe damage to nervous tissue, but the results have not demonstrated any significant variation from the normal, apart from one or two minor aspects. It has already been stated that some changes have been reported in the cerebrospinal fluid lipid profile in multiple sclerosis, but this is not surprising in any disease in which gross cerebral destruction takes place.

The technique used here for normal red cell lipids has yielded results very comparable with similar studies by Reed et al. (1960), although the more recent method of Ways and Hanahan (1964), which is now in use, should provide a more exact

TABLE IV

FATTY ACID COMPOSITION OF LECITHIN AND CHOLESTEROL ESTER IN WHITE MATTER ${ }^{1}$

\begin{tabular}{|c|c|c|c|c|c|}
\hline \multirow[t]{2}{*}{ Fatty Acids } & \multicolumn{4}{|l|}{ Lecithin } & \multirow{2}{*}{$\begin{array}{l}\text { Cholesterol Ester } \\
\text { Multiple Sclerosis } \\
\text { Plaque } \\
\text { Mean }\end{array}$} \\
\hline & $\begin{array}{l}\text { Normal } \\
\text { Mean } \pm \text { S.D. }\end{array}$ & $\begin{array}{l}\text { Multiple Sclerosis } \\
\text { Apparently Normal } \\
\text { Mean } \pm S . D .\end{array}$ & $\begin{array}{l}\text { Multiple Sclerosis } \\
\text { Plaque } \\
\text { Mean } \pm \text { S.D. }\end{array}$ & $\begin{array}{l}\text { Motor Neurone } \\
\text { Disease } \\
\text { Mean }\end{array}$ & \\
\hline $\begin{array}{l}\text { Saturated } \\
14: 0 \\
16: 0 \\
18: 0 \\
\text { Total }^{2}\end{array}$ & $\begin{array}{r}4 \cdot 66 \pm 1 \cdot 18 \\
27 \cdot 14 \pm 2 \cdot 74 \\
9 \cdot 40 \pm 2 \cdot 71 \\
42 \cdot 68 \pm 1 \cdot 34\end{array}$ & $\begin{array}{r}2 \cdot 05 \pm 1 \cdot 25 \\
27 \cdot 57 \pm 2 \cdot 67 \\
12 \cdot 15 \pm 1 \cdot 57 \\
45 \cdot 70 \pm 3 \cdot 26\end{array}$ & $\begin{array}{r}3.40 \\
31 \cdot 13 \pm 4.48 \\
9.53 \pm 1.57 \\
46.36 \pm 3.83\end{array}$ & $\begin{array}{r}2 \cdot 80 \\
26 \cdot 70 \\
11 \cdot 20 \\
41 \cdot 75\end{array}$ & $\begin{array}{c}5 \cdot 37 \\
30 \cdot 0 \\
4 \cdot 45 \\
44 \cdot 25\end{array}$ \\
\hline $\begin{array}{l}\text { Unsaturated } \\
16: 1 \\
18: 1 \\
20: 1 \\
20: 4 \\
\text { Total }\end{array}$ & $\begin{array}{r}5.08 \pm 2 \cdot 57 \\
45 \cdot 32 \pm 2 \cdot 36 \\
1.88 \pm 1 \cdot 10 \\
1.96 \pm 0 \cdot 58 \\
56 \cdot 12 \pm 1.60\end{array}$ & $\begin{array}{r}4.47 \pm 3.18 \\
38 \cdot 35 \pm 1 \cdot 75 \\
1 \cdot 57 \pm 0.88 \\
2 \cdot 20 \pm 0.98 \\
52 \cdot 20 \pm 3.98\end{array}$ & $\begin{array}{r}5.66 \pm 3.49 \\
40 \cdot 06 \pm 1 \cdot 81 \\
1.07 \\
2 \cdot 70 \\
52.60 \pm 5 \cdot 31\end{array}$ & $\begin{array}{r}4 \cdot 70 \\
45 \cdot 50 \\
2 \cdot 55 \\
2 \cdot 15 \\
57 \cdot 65\end{array}$ & $\begin{array}{r}17 \cdot 45 \\
27 \cdot 15 \\
2 \cdot 52 \\
2 \cdot 20 \\
54 \cdot 12\end{array}$ \\
\hline
\end{tabular}

${ }^{1}$ Values are expressed as percentage of total fatty acid methyl esters.

${ }^{2}$ Traces of other acids were present in total. 
TABLE V

FATTY ACIDS IN LECITHIN IN CEREBRAL WHITE MATTER (NORMAL) ${ }^{\mathbf{1}}$

Author

Saturated

Unsaturated

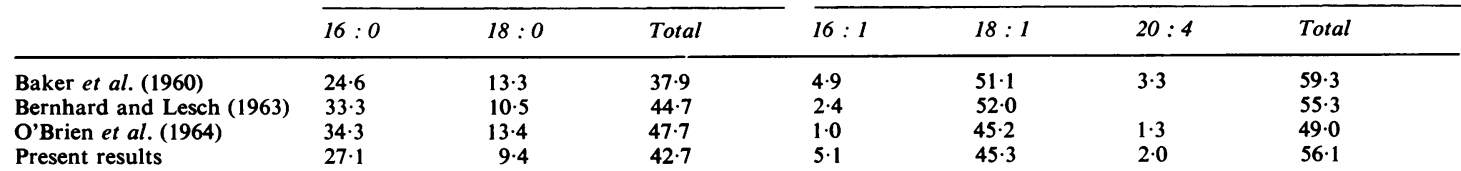

${ }^{1}$ Values are expressed as percentage of total fatty acid methyl esters.

appreciation of the facts and render results and comparisons more acceptable. The method of white cell separation yields large numbers of such cells, even though contaminated by a few red cells, but the figures for total lipid vary too widely for any reasonable comparisons to be made between normal and disease states. However the relative proportions of the four major constituents show considerably less variation and yet do not show significant differences between the controls and either multiple sclerosis or motor neurone disease.

The fatty acid composition of both lecithin and cholesterol esters in plasma as seen in the normals (Tables II and III) are very similar to those recorded by Hanahan, Watts, and Pappajohn (1960) and by Blomstrand (1960); thus the absence of any marked abnormality found in multiple sclerosis plasma is of importance. It is true that in cholesterol esters there is a slight reduction in total saturated fatty acids but the unsaturated fatty acids are not significantly altered. Indeed linoleic acid $(18: 2)$, although at slightly higher levels in multiple sclerosis plasma as compared with our value in normals is still lower than the corresponding normal figure of Blomstrand (1960). The values for fatty acids in plasma lecithin obtained by Hanahan et al. (1960) are very similar to those reported here, so that the lack of abnormality in multiple sclerosis plasma is worthy of note.

There are a few more reports relating to normal brain lecithin and these are briefly given in Table V. It is seen that there is some degree of variation, for the results obtain by O'Brien, Fillerup, and Mead (1964) demonstrate a rather higher content of saturated and a lower level of unsaturated fatty acids than do those of other workers, while the figures reported here lie midway between those of Baker et al. (1963) and those of O'Brien et al. (1964), and are very similar to those recently published by Bernhard and Lesch (1963). These last authors found marked differences between different areas of the brain, especially between the cortex and the white matter. These variations render it more difficult to comment on minor abnormalities, but as a similar change was present in both the plaques and the ap- parently normal white matter in multiple sclerosis, the finding of a slight increase in saturation with a decrease in oleic acid $(18: 1)$ may be of significance. However, the figures obtained are within the normal range of O'Brien et al. (1964) so that caution in interpretation must be observed. No other observations relating to motor neurone disease are available for comparison but the findings reported here for white matter lecithin were not abnormal.

Baker et al. (1963), in commenting on their results, state that possible causes of change in the fatty acid composition of lecithin in the apparently normal white matter in multiple sclerosis might be due to a defect in synthesis, a dietary deficiency, or a failure in intestinal absorption. Regarding this latter suggestion, it is of interest that in a small series of patients studied in parallel with a similar control group no abnormality in the standard xylose absorption test using $25 \mathrm{~g}$. doses of xylose has been found. This would be some slight evidence against an abnormality of intestinal absorption in multiple sclerosis.

Our thanks are due to a generous grant from the Ministry of Health Clinical Research Board.

\section{REFERENCES}

Baker, R. W. R., Thompson, R. H. S., and Zilkha, K. J. (1963) Lancet, $1,26$.

Bernhard, K., and Lesch, P. (1963). Helv. chim. Acta, 46, 1798.

Blomstrand, R. (1960). Acta chem. scand., 14, 775.

Brown, J. L., and Johnston, J. M. (1962). J. Lipid Res., 3, 480.

Cumings, J. N. (1953). Brain, 76, 551.

Folch, J., Lees, M., and Sloane Stanley, G. H. (1957). J. biol. Chem., 226, 497.

Hanahan, D. J., Watts, R. M., and Pappajohn, D. (1960). J. Lipid Res., $1,421$.

Lalezari, P. (1961). Fed. Proc., 20, No.1. Part 1. 71.

McArdle, B., and Zilkha, K. J. (1962). Brain, 85, 389.

Müldner, H. G., Wherrett, J. R., and Cumings, J. N. (1962). J. Neurochem., 9, 607.

O'Brien, J. S., Fillerup, D. L., and Mead, J. F. (1964). J. Lipid Res., 5, $\sigma$ 329.

Phillips, B. M., and Robinson, N. (1963). Clin. chim. Acta, 8, 832. Reed, C. F., Swisher, S. N., Marinetti, G. V., and Eden, E. G. (1960). J. Lab. clin. Med., 56, 281.

Robinson, N., and Phillips, B. M. (1963). Clin. chim. Acta, 8, 385.

Stoffel, W., Chu, F., and Ahrens, E. H. (1959). Analyt. Chem., 31, 307. Wagner, H., Hörhammer, L., and Wolff, P. (1961). Biochem. Z., 334, 175.

Ways, P., and Hanahan, D. J. (1964). J. Lipid Res., 5, 318.

Zilkha, K. J., and McArdle, B. (1963). Quart. J. Med., 32, 79. 